\title{
ULAMA DAN WACANA ISLAM DALAM HUBUNGAN INTELEKTUAL DI TANAH MELAYU DAN INDONESIA \\ (ISLAMIC SCHOLARS AND DISCOURSE OF INTELLECTUAL RELATIONS IN MALAYA AND INDONESIA)
}

${ }^{1}$ Badlihisyam Mohd Nasir, ${ }^{2}$ Rahimin Affandi Abd. Rahim, ${ }^{3}$ Ridzwan Bin Ahmad \& ${ }^{4}$ Khafidz Hamzah

${ }^{1}$ Fakulti Tamadun Islam, Universiti Teknologi Malaysia

2,3,4Akademi Pengajian Islam, Universiti Malaya,

(badlihisham@utm.my, faqir_ila_rabbih@um.edu.my, ridzwan@um.edu.my, khafidz.hamzah@siswa.um.edu.my)

\begin{abstract}
This article is about the Islamic discourse upon the role of the ulamak and the intellectual relationship in enriching the Muslim civilization in Malaysia and Indonesia. At the outset, it will explore the significance of the Malay-Muslim civilization as well as the major role played by the ulamak in the development of Muslim civilization in the Malay Archipelago. The main focus of this article will concentrate on several issues, specifically Terengganu's Batu Bersurat, the discourse of the Kaum Muda-Tua in the 1930s, the dakwah movement during the 1970s and the Islamization of knowledge. Finally, the intellectual discourses that enrich Malay-Muslim knowledge as resources in coping with the forced modernization initiated by western powers in the Malay Archipelago is summed up.
\end{abstract}

Keywords: ulamak, Kaum Muda-Tua, Batu Bersurat Terengganu, dakwah, Islamization of Knowledge

\section{Pengenalan}

Mengikut para sejarahwan dunia, agama berperanan besar dalam membina sesuatu dunia. Hal ini tidak terkecuali dengan sejarah Tanah Melayu, bila mana agama Hindu Budhha pernah membina Tamadun Tanah Melayu. Tamadun binaan agama Hindu Budhha ini agak eksklusif sifatnya (berasaskan sistem kasta) (M.Rajantheran, 2001, h. 49-60) yang lebih bertumpu kepada golongan raja dan 
bangsawan semata-mata tanpa membabitkan masyarakat bawahan. Realiti ini kemudiannya berubah dengan berlakunya proses Islamisasi Tanah Melayu. Islam telah berjaya memajukan daya intelektual masyarakat secara keseluruhan dan mewujudkan masyarakat yang lebih egaliterian. Terpenting sekali Islam telah mengubah world-view masyarakat Melayu kepada world-view tauhid. Hal ini berlaku dengan wujudnya mekanisme pendidikan Islam yang dibangunkan oleh mubaligh yang awal. Hasil didikan sistem pendidikan Islam ini telah melahirkan serangkaian ulamak yang memainkan peranan besar dalam memajukan Tamadun di Tanah Melayu. Atas dasar ini, artikel ini akan cuba menganalisa peranan ulamak dalam pembinaaan tamadun di Tanah Melayu. Untuk tujuan itu, beberapa fokus dan tema akan dipilih membabitkan isu hubungan intelektual antara ulamak Malaysia dan Indonesia.

\section{Asas dan Kepentingan Sesuatu Tamadun}

Sarjana menegaskan terdapat beberapa kepentingan tamadun; Pertama, mewujudkan perpaduan untuk mengekalkan hayat sesuatu masyarakat. Pada pandangan Ibnu Khaldun, umur sesebuah tamadun secara hukum alami akan melalui tiga tahap yang utama; tahap kelahiran, kemajuan dan kemunduran (Saleh Faghizadeh, 2004, h. 63-68). Atas dasar itu, kajian dan usaha penambahbaikian perlu dilakukan melalui kajian ilmu untuk memanjangkan usia sesebuah tamadun. Untuk itu, Ibn khaldun telah memperkenalkan disiplin sosiologi-sejarah yang bertujuan untuk meneliti hukum alami fenomena sesebuah masyarakat, samada menafsirkan sesuatu fenomena sosial masyarakat dalam bentuk perkaitan sebab musabab (Toto Suharto, 2003, h. 87-103) ataupun meramalkan jalan penyelesaian terhadap sesuatu permasalahan yang timbul (Abdullah Mohd. Said, 2003). Bagi Ibn Khaldun penggunaan disiplin sosiologisejarah ini tidak boleh dibuat secara spekulatif (agakan) semata-mata, tetapi perlu dilakukan secara berhemah. Ianya perlu berasaskan kerangka kajian ilmiah yang bersifat objektif, mementingkan sumber kajian yang tepat, tafsiran sumber yang betul dan pengaplikasian metodologi kajian kes (observasi) yang betul (Mahayudin Haji Yahya, 1999, h. 10-11). Penggunaan disiplin sosiologi-sejarah yang ketat ini bermatlamatkan untuk memahami realiti sebenar perubahan masyarakat yang berlaku dan menawarkan ramalan penyelesaian masalah terhadap apa-apa masalah sosial yang timbul.

Kedua, tamadun atau pembangunan menyediakan manafaat keperluan asasi kepada ahli masyarakat. Terdapat kayu ukur bagi menilai kejayaan ataupun kegagalan sesuatu program pembangunan; (i) adakah agihan pendapatan negara dapat dibahagikan secara seimbang kepada semua lapisan masyarakat (Chamhuri Siwar, 2002, h. 119-145); (ii) adakah program pembangunan dapat menyediakan kepada rakyat keperluan asas seperti life-sustenance (makanan, perumahan, 
kesihatan dan perlindungan), self-esteem (peluang pekerjaan, pendidikan yang bermutu dan kemajuan sosio-budaya) dan freedom from servitude (kebebasan individu untuk memilih dan bebas daripada sebarang belenggu dan pergantungan kepada orang lain) (Abdul Rahman Aziz, 2004, h. 19-22); (iii) adakah nikmat ataupun manafaat yang diharapkan daripada program pembangunan diterima ataupun tidak oleh golongan sasaran (Che Su Mustaffa, 1996, h. 69-80); (iv) adakah program pembangunan dapat memupuk semangat jati diri, perpaduan dan patriotisme di kalangan rakyat (Abdul Rahman Aziz, 2004), dan (v) adakah program pembangunan dapat menjaga keseimbangan ekologi (Rumaya Juhari, 2004, h. 10-16).

Ketiga, tamadun bakal mewariskan kepada generasi pelapis sistem nilai dan agama milik ahli masyarakat. Hal ini termasuk penggunaan akal untuk menanggani alam sehingga melahirkan kearifan tempatan. Kearifan tempatan bukanlah membawa maksud local genius (kepandaian tempatan) yang kerap digunakan oleh sarjana Barat. Perkataan Arif ini membawa maksud mengetahui secara mendalam ataupun bijaksana kerana didasarkan kepada pemikiran yang mendalam. Ianya biasa digunakan untuk melambangkan kebijaksanaan seseorang yang mencapai maqam al-Arifin.

Berbanding dengan neraca Barat, tradisi golongan arif atau intelektual Melayu-Islam boleh dirujuk kepada golongan ulamak, tua dan pemimpin masyarakat. Mereka biasanya bertindak dalam beberapa kapasiti yang khusus, merangkumi; (i) sebagai pemikir, pendidik dan mengatur hubungan masyarakat agar menjadi lebih harmonis dan mengelakkan huru hara; (ii) manusia Rabbani yang mengaitkan hubungan dengan alam, masyarakat dan Allah; (iii) pemikir yang responsif dengan realiti semasa, dan (iv) pemikir yang berinteraksi dengan alam sehingga melahirkan konsep pengalaman (berguru dan belajar dengan alam) (Rahimin Affandi Abd Rahim, 2011).

Konsep kearifan tempatan ini bersesuaian dengan teori bahawa setiap manusia memiliki keupayaan akal untuk membina tamadun sendiri. Ia memerlukan elemen bantuan pengaruh asing atau sumber daripada luar diri manusia dan akal untuk maju. Ia membabitkan ilham dan laduni daripada Allah. Disini letaknya peranan Allah dalam membekalkan akal dan alat (alam dan makhluk tunduk kepada manusia) untuk membantu manusia membangunkan tamadun. Seperti mana halnya direkodkan peranan Hims (nabi Allah Idris) dalam mengajar pelbagai ilmu kepada manusia awal sehingga menjadi asas tamadun awal Timur Tengah. Apa yang jelasnya, proses berfikir memerlukan imput dan sumber serta alat bagi membolehkan manusia berfikir dengan baik. Campuran antara akal dan hubungan dengan Allah (sumber tasawuf) akan melahirkan kebijaksanaan kepada manusia (Rahimin Affandi Abd. Rahim, 2013, h. 223-245). 
Hal ini kemudiannya telah melahirkan epistemologi ilmu kepada masyarakat Melayu. Tidak keterlaluan jika dikatakan bahawa epistemologi manusia Melayu terdiri daripada beberapa perkara yang utama;

1. Bentuk Bayani (bergantung kepada teks wahyu), Burhani (bergantung kepada akal) dan Irfani (bergantung pada intuisi dan ilham). Ketiga-tiga bentuk ini telah diintegrasikan pemakaiannya oleh manusia Melayu (Rahimin Affandi Abd Rahim, 2009).

2. Rasionalisme dan emperiscisme sekaligus. Hal ini jelas terbukti apabila manusia Melayu menekankan kepada menumpukan pembelajaran dengan alam semesta (Ayat Kawniyyah) sehingga terhasil teori/hukum alam (konsep adat) yang bersifat kekal (seperti perpatah biar mati anak jangan mati adat) dan bersifat fleksibel yang perlu berubah mengikut keperluan semasa (seperti perpatah sekali air bah sekali pasir pantai berubah) (Abdullah Alwi haji Hassan, 2001, h. 65-66).

3. Bentuk penggunaan akal melalui metafora, alegorikal dan rasional. Ia terdiri daripada Aktual (potensi dan fitrah yang dimiliki sejak manusia lahir- bersifat tidak berkembang) dan Muktasab (diperolihi dengan cara belajar, membaca dan mengkaji -bersifat sentiasa berkembang) (Hassan Ahmad, 2004, h. 1-12).

4. Bentuk penelitian sesuatu fenomena kehidupan dan alam secara mendalam. Banyak perpatah Melayu tentang konsep sains lahir hasil interaksi akal dengan pengalaman hidup dan alam semesta (Ithnin Abdul Jalil, 2001, h. 452460). Ia dikaji oleh pemikir Melayu secara mendalam dan berulang kali, yang kemudiannya dinukilkan dalam bentuk perpatah untuk dimanafaatkan oleh anggota masyarakat (Hassan Ahmad, 2004, h. 1-12).

\section{Peranan Ulamak dalam Pembinaan Tamadun Tanah Melayu}

Dalam bahagian ini, secara lebih mikro lagi, kita akan mendedahkan peranan ulamak Islam dalam pembinaan tamadun di Tanah Melayu. Tidak keterlaluan jika dikatakan bahawa dalam sejarah Alam Melayu, Islam bertindak sebagai kuasa pemangkin utama yang mewujudkan tamadun material dan intelektual yang unggul di rantau Alam Melayu. Teori ini menegaskan bagaimana peranan Islam akan sentiasa dianggap relevan untuk konteks masyarakat Melayu untuk setiap zaman, termasuklah untuk konteks zaman moden ini. Apa yang lebih penting lagi, fungsi Islam ini dapat dihidupkan dengan usaha yang gigih yang dimainkan oleh ulamak Melayu (Rahimin Affandi Abd. Rahim, 2005, h. 19-51). Jika dirujuk kepada sejarah perkembangan Islam di Alam Melayu, kita boleh menegaskan secara pasti bahawa ulamak Melayu telah mampu untuk bertindak sebagai intelektual ummah dalam beberapa perkara.

Antaranya, pertama, perancang kepada usaha yang berkesan untuk memperkenalkan agama Islam ke dalam masyarakat Melayu (Abdul Halim el- 
Muhammady, 1992, h. 173-184). Kedua, pembasmi nilai-nilai feudalism dan adat pra-Islam yang berakar umbi di dalam kehidupan masyarakat melalui institusi pendidikan Islam (Rahimin Affandi Abd. Rahim, 2000, h. 22-25). Ketiga, penanam benih budaya ilmu ke dalam masyarakat Melayu yang mampu melahirkan sejumlah manusia Melayu yang celek agama serta mampu bertindak mengikut perkiraan ilmunya, menyebarkannya ke dalam masyarakat dan berfungsi sebagai pemimpin masyarakat (Shafie Abu Bakar, 1994, h. 101-103). Ianya juga telah melahirkan manusia Melayu yang berakhlak tinggi (Abdullah Ishak, 1982, h. 202204) dan mampu berdikari tanpa bergantung kepada orang lain (Abdullah Ishak, 1982, h. 202-204). Keempat, pemangkin kepada usaha penerapan nilai-nilai Islam ke dalam kebudayaan masyarakat Melayu (Mohd. Taib Osman 1996, h. 278-280) sehingga Islam kemudiannya telah menjadi jati diri yang utama kepada kelangsungan diri manusia Melayu (R.O. Winstedt, 1969, h. 288).

Kelima, penasihat kepada pemerintah Melayu (Mohd. Yusof Iskandar, 1982, h. 52-53) di dalam usaha menerapkan nilai-nilai Islam ke dalam sistem undang-undang masyarakat Melayu (Ismail Mat, 1997 h. 89-90), sehingga melahirkan sejumlah Malay degist Melayu Islam (Abdul Rahman Abdullah, 1982, h. 59-63). Keenam, perancang dan pencipta sistem kominikasi dakwah (tulisan jawi) yang berkesan di dalam masyarakat yang kemudiannya telah menjadi bahasa perantaraan (lingua franca) untuk perkembangan ilmiah Islam (Omar Awang, 1981, h. 80-85) dan hubungan antarabangsa (Mohammad Redzuan Othman, 1994, h. 53-55). Ketujuh, perancang kepada usaha memperkayakan kesenian (Ahmad Kamal Abdullah, 1988, h. 47-48; Shafie Abu Bakar, 1987, h. 95; Mohd. Anis Md. Nor, 1990, h. 30-38) dan kesusasteraan Melayu Islam. Kelapan, perancang kepada usaha mempereratkan hubungan antara umat Melayu dengan serangkaian umat Islam seluruh dunia (internationalism) di bawah konsep ummah Islam (Nabir Abdullah, 1987, h. 129-142). Kesembilan, sumber inspirasi kepada usaha menerapkan semangat perang salib di dalam memerangi kuasa penjajah Barat (Abdul Rahman Abdullah, 1994). Kesepuluh, bertindak sebagai benteng terakhir ummah dan pakar rujuk masyarakat yang dilanda krisis kekeliruan akibat dari penerapan faham sekularisme yang diusahakan oleh penjajah British (Mohammad Redzuan Othman, 2001, h. 254-256) Kesebelas, pencetus semangat nasionalisme Melayu yang awal dilihat dari dua aspek (i) usaha menghapuskan kemungkaran dan kezaliman yang berlaku di dalam masyarakat Melayu (Abdul Rahman Haji Ismail, 1995, h. 163-192) dan (ii) usaha membebaskan diri dari belenggu penjajahan kuasa asing (Mohammad Redzuan Othman, 1988, h. 154) Kedua belas, perancang utama yang melahirkan golongan literati Melayu pertama yang menanamkan sikap kritikal terhadap proses pemodenan yang dibawa oleh penjajah British (Mohd. Sarim Mustajab, 1982, h. 151-152). 


\section{Alam Melayu Sebagai Kawasan Islam yang Ekslusif}

Dalam perkembangan semasa, kawasan rantau Alam Melayu telah dianggap sebagai suatu kawasan penting dan esklusif (Mohamad Raduan MoM. Ariff \& Shaharil Talib, 1995, h. 131-146) di dalam kerangka kajian regional studies untuk subjek kawasan masyarakat Islam (John Esposito, 1996). Ianya tergolong sebagai kawasan milik Malaysia dan Indonesia (Shaharil Talib, 1997, h. 123-135). Ianya dibezakan dengan kawasan Timur tengah, Indonesia-Pakistan, Afrika, Eropah dan Amerika utara. Penetapan kawasan rantau Alam Melayu (Malay Achipleago) yang berbeza dengan kawasan lain dibuat berasaskan kepada pelbagai elemen persamaan yang membabitkan kedua kawasan (Indonesia dan Malaysia) (Peter Riddell, 2001).

Persamaan ini antara lainya merujuk kepada; pertama, kedua-dua lokasi mempunyai perkaitan yang erat dilihat dari sudut sejarah hubungan persaudaraan Melayu yang berasaskan kepada jalinan intelektual keagamaan. Kedua; kedua-dua lokasi merupakan kawasan dunia Melayu-Islam terbesar yang mengamalkan dan memperkembangkan pemikiran Islam menggunakan bahasa pengantar yang sama, bahasa Melayu. Ketiga; persamaan latar belakang sejarah Islamisasi, pengamalan mazhab yang sama dan institusi pengajian keilmuan Islam yang saling mempengaruhi dilihat dari sudut perkembangan tren reformasi pendidikan Islam semasa (Rahimin Affandi at.al, 2010, h. 13-32), dan keempat; kewujudan jalinan intelektual yang kukuh di antara kedua kawasan. Ianya merujuk kepada aspek teologi dan syariah yang sama berasaskan kepada Mazhab Shafi'i. Ulamak dari kedua kawasan sering bertukar pandangan dan bantuan intelektual sejak dari zaman awal, tahun-tahun 1900an dan semasa era kebangkitan Islam di tahun-tahun 1970-1980an (Rahimin Affandi Abdul Rahim, 2003, h. 47-74).

Sarjana Barat sering menonjolkan sifat ajaran Islam di Alam Melayu (Malaysia dan Indonesia) sebagai Islam pinggiran yang bukannya murni kerana bercampur dengan pelbagai bentuk khurafat dan Bid'ah. Hal ini berbeza dengan sifat Islam di Timur Tengah yang dikatakan lebih bersifat sejati dan murni yang perlu dipelajari dan dicontohi secara mutlak (Azyumardi Azra, 1999, h. 5-7). Atas dasar ini, kita boleh melihat bagaimana kalangan orientalis barat yang menyusun buku Encylopadia of Islam lebih menumpukan perhatian mereka kepada ulamak Timur Tengah dan Indonesia-Pakistan dan bukannya kepada ulamak di kawasan pinggiran seperti rantau Alam Melayu. Dari perkembangan terbaharu, kita dapat melihat hanya satu sahaja buku Encylopadia, iaitu Encylopadia of Oxford yang turut memberikan tumpuan kepada sumbangan ulamak di kawasan Alam Melayu ini.

Keabsahan teori ini kemudiannya telah mula dicabar dengan kedatangan era globalisasi, yang menyaksikan bagaimana peta pusat pengajian ilmu-ilmu 
Islam dunia telah terbahagi kepada tiga jenis yang utama; (i) dunia Barat yang berteraskan kaedah ala orientalism (Faisal Ismail, 1997, h. 35-42); (ii) dunia Islam Timur tengah yang lebih menumpukan kepada kerangka pengajian ala tradisionalism (Yusri Ihza Mahendra, 1994, h. 12-19) dan (iii) dunia Alam Melayu (Malaysia dan Indonesia) yang dilihat telah mengadunkan di antara kerangka ala tradisionalism dan reformism sekaligus (Rahimin Affandi Abdul Rahim, 2005, h. 105-134).

Walaupun dunia Alam Melayu sering didakwa sebagai pusat pengajian Islam ala peripheral, ternyata pendekatan Alam Melayu (Malaysia dan Indonesia) telah mendapat sambutan dan momentum yang cukup baik, sehingga dikatakan sebagai nisbah utama ajaran Islam ala Nusantara yang bersifat lembut, toleran dan terbuka dengan perkembangan moden semasa (Rahimin Affandi Abdul Rahim, 2005, h. xv-xvi).

Sayugia dimaklumkan, di zaman 1960an IPTA di Indonesia sering dijadikan tumpuan oleh pelajar Islam untuk mendapat pendidikan di peringkat ijazah pertama dan pasca sarjana. Namun begitu, dalam perkembangan semasa, bentuk hubungan antara IPTA Islam Malaysia dan Indonesia telah mula berubah yang dapat dinilai beberapa perkara yang utama;

Pertama, pertambahan jumlah pelajar pasca siswazah Indonesia di IPTA Islam di Malaysia. Jika di zaman selepas Malaysia merdeka, IPTA Malaysia memerlukan khidmat kalangan sarjana Indonesia bagi membangunkan program pengajian Islam di pelbagai IPTA, hal yang sebaliknya telah berlaku dewasa ini apabila serangkaian pelajar pasca siswazah Indonesia yang datang ke Malaysia bagi mendapatkan khidmat nasihat untuk menamatkan pengajian mereka di peringkat pasca siswazah (Akh. Minhaji, 2003, h. 62-80).

Kedua, kelebihan Malaysia dalam membangunkan program keIslaman yang lebih bersifat moderate and praktikal, dirujuk antara lainnya dengan program pembangunan sistem ekonomi Islam, reformasi pendidikan Islam and sebagainya. Apa yang lebih penting lagi, sarjana Indonesia sendiri telah mengakui keunggulan peranan Malaysia ini yang dikaitkan dengan pembangunan idealism Islam yang berkesan yang ditunjukkan oleh pihak kerajaan sendiri (Akh. Minhaji, 2003, h. 62-80).

Ketiga, kerana beberapa kengkangan sosio-politik, banyak daripada idea canggih yang disuarakan oleh sarjana Indonesia gagal dilaksanakan secara berkesan di dalam masyarakat. Atas dasar inilah tidak salah seandainya peranan ini perlu dimainkan oleh kalangan pemikir dan pembuat dasar di Malaysia $(\mathrm{H}$. Faisal Ismail, 2005, h. 135-138).

Keempat, bahan penerbitan Islam daripada Malaysia kurang diberi peluang untuk berkembang di Indonesia secara luas dan terpaksa berhadapan dengan pelbagai kekangan birokrasi dari pihak berkuasa Indonesia (Hamedi Mohd Adnan, 2006). 


\section{Sejarah Hubungan Ulamak Malaysia dan Indonesia di Alam Melayu}

Sejak daripada awal pengislaman Alam Melayu, kita dapat menyaksikan bagaimana ulamak Tanah Melayu sangat bergantung kepada bantuan ulamak Indonesia dalam menanggani isu-isu Islam. Bahkan ia telah sampai satu peringkat bahawa hubungan ini bersifat berat sebelah. Hal ini kemudiannya telah mula berubah di zaman moden. Apa yang ingin ditonjolkan adalah hubungan kedua ulamak dari kedua kawasan ini bersifat complimentary (saling melengkapi) demi untuk kepentingan dakwah Islam.

Dalam sejarah hubungan rantau Tanah Melayu dan Indonesia, kita dapat mengesan beberapa perkara utama;

\section{Terengganu Sebagai Jajahan Takluk Empayar Islam di Indonesia (Kalimantan)}

Mengikut neraca zaman silam, setiap jajahan takluk sesuatu empayar akan menjalankan dasar yang sama dengan pusat empayarnya (Bagoes Wiryomartono, 2012, h. 115-130). Atas dasar itu, apa yang dijalankan oleh empayar pusat di Indonesia akan turut dijalankan oleh jajahan takluknya yang lain (Mohammad Raduan bin Mohd.Ariff, 1997, h. 138-146), dan dalam konteks ini mendorong pengislaman Terengganu. Maklumat ini boleh didapati daripada penemuan Batu Bersurat di Terengganu. Dalam catatan Batu bersurat di Terengganu ini kita dapat mengesan beberapa perkara utama; pertama, Terengganu adalah jajahan takluk empayar Islam Indonesia, bila mana gelaran pemerintah iaitu Mandulika telah turut dipakai. Gelaran Mandulika ini adalah ketua kerajaan di Indonesia yang kemudiannya bertanggungjawab mengislamkan dan menerapkan hukum Islam di jajahan takluknya di Indonesia dan Terengganu di Tanah Melayu. Kedua; fakta bahawa Terengganu sebagai tempat terawal di tanah Melayu yang menerima dan mengamalkan ajaran Islam secara menyeluruh. Sebelum ini, terdapat teori yang mendakwa Melaka merupakan tempat terawal menerima ajaran Islam di Tanah Melayu, yang dikaitkan juga sebagai pusat yang memperkembangkan Islam ke seluruh jajahan takluk empayar Melaka yang lain. Secara mudahnya, kita dapat mengatakan bukti tempat awal menerima Islam perlu didasarkan kepada wujudnya beberapa artifak yang khusus, merangkumi (i) kitab atau manuskrip agama, (ii) masjib tertua, (iii) institusi pendidikan Islam seperti pondok, (iv) kubur seseorang ulamak dan (v) terpenting sekali pengaruh pemikiran Islam yang berkekalan serta dapat dikesan penggunaanya secara meluas di dalam masyarakat (S. Hossein Nasr, 1990, h. 13). Seandainya bukti-bukti ini mahu diambilkira, kita akan bersetuju bahawa kawasan pantai Timur Tanah Melayu lebih memenuhi syarat bukti ini, kerana kesemua artifak dan bukti ini memang terdapat secara lengkap di kawasan pantai Timur seperti Terengganu dan Kelantan, dan bukannya di kawasan Pantai Barat Tanah Melayu. 
Ketiga; proses penciptaan tulisan Jawi terawal di Alam Melayu. Kita mungkin tidak tahu siapa dan tarikh sebenar tulisan Jawi diperkenalkan untuk konteks Alam Melayu. Namun begitu, mengikut Omar Awang tulisan Jawi yang dikesan dalam BBT merupakan tulisan paling awal dan lengkap sekali (Omar Awang, 1981, h. 80-85). Terpenting sekali, penciptaan dan penggunaan tulisan Jawi dalam masyarakat Melayu telah memperkayakan bahasa Melayu (Amran Kasimin, 1987) dalam bentuk tulisan Jawi, yang dijadikan sebagai alat untuk memperkembangkan keilmuan Islam. Sistem pengajian agama dalam bentuk pengajian pondok telah menggunakan bahasa wilayah Timur Laut melalui sistem tulisan Jawi. Fenomena yang mengambilkira elemen tempatan dalam bentuk memilih bahasa tempatan sebagai medium untuk penyebaran ilmu agama telah dilakukan oleh sarjana Islam di kebanyakan dunia Islam, seperti penciptaan tulisan Urdu di India dan tulisan Parsi di Iran berteraskan dari segi bentuknya kepada bahasa Arab dengan sedikit sebanyak pengubahsuaian (Omar Awang, 1980, h. 55).

Keempat; Unsur Islam dapat dikesan di dalam BBT, di mana Islam telah memberi nafas sebenar kepada pembinaan world-view (pandangan alam semesta) Melayu (Abdul Rahman Abdullah, 1999). Hasil penelitian yang dibuat oleh Prof. Hashim Musa mendapati pembinaan tamadun Melayu ini telah diasaskan dengan enam pandangan world-view yang bersumberkan wahyu Allah. Keenam-enam pandangan ini telah menjadi pegangan utama masyarakat Melayu (konsep jati diri Melayu) sehingga pada masa sekarang. Pemilihan Islam sebagai asas jati diri ini ternyata telah menguntungkan masyarakat Melayu kerana seperti mana berlaku kepada masyarakat Arab, Islam juga telah mengangkat martabat tamadun Melayu ke peringkat antarabangsa (Abdul Rahman Abdullah, 1999, h. 50). Proses ini antara lainnya telah menimbulkan semangat perpaduan (internationalism) di kalangan umat Melayu bahawa kedudukan mereka di dalam kerangka Tauhid, Ummah dan ukhuwwah bukan terhad kepada lingkungan kawasan dan sejarah alam Melayu semata-mata bahkan turut membabitkan kesemua umat Islam seluruh dunia dari setiap zaman dengan warisan tamadun yang tinggi (Rahimin Affandi Abdul Rahim, 2000, h.18-19). Dengan konsep jati diri ini umat Melayu berasa berbangga menganut Islam yang menjadikan mereka sebahagian daripada serangkaian ummah Islam, seperti mana halnya golongan Arab yang dipandang mulia oleh masyarakat Melayu (William Roff, 1980, h. 41). Faktor inilah juga yang menyebabkan di dalam sejarah alam Melayu kerap berlaku penentangan umat Melayu terhadap kuasa penjajah barat yang dianggap sebagai kuasa kafir (Abdul Rahman Abdullah, 1994) dan hal ini telah diakui sendiri oleh mubaligh Kristian yang mengatakan bahawa orang Melayu sebagai golongan yang kuat berpegang kepada agama Islam (Charles Tisdall, 1916, h. 348-349). Apa yang jelasnya, sifat keMelayuan yang begitu sebati dengan Islam ini telah mengakibatkan sebarang 
serangan yang dibuat terhadap Islam akan dianggap seperti serangan yang dibuat terhadap asas kebudayaan Melayu (Isabella Bird, 1967, h. 20).

Kelima; dalam BBT tercatat pengisytiharan Islam sebagai agama rasmi di Terengganu yang disertakan dengan pelaksanaan undang-undang Islam oleh Mandulika (gelaran pemerintah Indonesia) bertarikh 22 Februari 1303M. Bagi D.G.E. Hall, proses pendidikan dan perundangan Islam telah bertapak lebih daripada seratus sebelumnya (D.G. E. Hall, 1968 h. 255). Hanya selepas Islam benar-benar diterima ramai dan menjadi asas kehidupan masyarakat Melayu di Terenganu, barulah ianya dicatatkan pada BBT sebagai pengisytiharan dan peringatan tentang kedaulatan Islam di kawasan tersebut. Ada keterangan tentang Allah dan Rasul, disamping bukti bahawa sistem perundangan Islam berupa gabungan antara undang-undang adat dan Islam (M.B. Hooker, 1976, h. 127-131). Ia membabitkan 9 atau 10 hukum dalam bidang (a) mu'amalat - tentang hutang piutang, undang-undang keterangan, hukuman kerana enggan membayar denda atau melarikan diri daripada hukuman dan (b) hukuman bagi kesalahan zina (Abdul kadir Muhammad, 1996, h. 4).

\section{Hubungan Politik dan Wacana Ilmu antara Tanah Melayu dan Indonesia}

Fakta sejarah mencatatkan bagaimana kedua kawasan mempunyai hubungan keilmuan yang amat erat. Dalam tradisi ilmu Islam, telahpun wujud pendekatan yang mengakui autoriti dan hiraki ilmu. Andainya terjadi apa-apa masalah agama, rujukan kepada autoriti atasan akan dibuat. Dalam sejarah kerajaan Melaka ada tercatat kes masalah Usuludin yang gagal dijawab telah dirujuk kepada majlis ulamak di kerajaan Samudra Pasai. Isunya membabitkan soalan adakah syurga dan neraka telahpun wujud pada masa sekarang.

Dalam contoh yang lain, terdapat catatan bagaimana Nuruddin Al-Raniri telah dilantik sebagai penasihat agama tertinggi di kerajaan Samudra Pasai. Beliau juga turut dilantik atas kapasiti yang sama di kerajaan Pahang, apabila beliau berkunjung ke negeri tersebut (Abdul Rahman Abdullah, 1990, h. 127-130). Ini antaranya menunjukkan bahawa hubungan intelektual dan politik kerajaan Melayu di Alam Melayu memang rapat tanpa memperkirakan semangat kesukuan yang sempit. Hal ini kemudiannya telah berubah dengan datangnya penjajah British dan Belanda yang membawa semangat asabiyyah sempit berasaskan kepada konsep Nation State. Jauh sebelum kedatangan kuasa penjajah barat, masyarakat Alam Melayu telah berhubungan dengan cukup damai dan saling melengkapkan antara satu sama lain (Rahimin Affandi Abdul Rahim, 2005, h. 19-51).

Dalam aspek sosial kemasyarakatan pula, kita boleh mengesan beberapa perkara utama; pertama, Kerajaan Melayu-Islam di Negeri Sembilan, Selangor dan beberapa daerah lain telah dibangunkan oleh masyarakat Islam daripada Indonesia. Atas dasar ukhuwah Islam masyarakat Tanah Melayu menerima 
kedatangan saudara mereka daripada Indonesia dengan hati yang terbuka (Meor Ahmad Noor Mior Hamzah , 2001, h. 66-96), dan kedua, penduduk asal Acheh bebas berhijrah ke kawasan utara Tanah Melayu samada sebagai peniaga, ulamak dan pejuang Islam untuk menentang penjajahan kuasa Barat.

\section{Jalinan Intelektual Kaum Muda dan Kaum Tua}

Rekord sejarah Tanah Melayu ada mencatatkan bagaimana ulamak daripada kedua aliran reformisme dan tradisionalisme di kedua kawasan memang saling berhubungan untuk memperkukuhkan aliran pemikiran masing-masing. Ulamak Indonesia sering dijemput datang ke Tanah Melayu untuk berhujah dan mngeluarkan pandangan dalam isu pertentangan ini. Majalah dan bahan buku daripada Indonesia juga tersebar meluas di Tanah Melayu (Ibrahim Abu Bakar, 1994, h. 165-166).

Pertentangan Kaum Muda - Tua ini memperlihatkan bagaimana; pertama; Ulamak proaktif dengan perkembangan di zaman mereka, dan bukannya menjadi penyaksi peristiwa sejarah semata-mata tetapi turut berusaha menanggani isu ini dengan proaktif dan kedua, pertentangan kaum muda-tua ini berlaku kerana faktor perbezaan falsafah, aliran dan paradigma menggunakan Islam untuk menghadapi keperluan zaman. Hal ini kemudiannya tidak mati begitu sahaja bahkan masih diteruskan hingga pada zaman moden ini. Banyak idealism dipegang oleh kedua aliran ini masih lagi kekal hingga zaman moden. Beberapa contoh boleh diberikan, antaranya;

1. Banyak sekolah dan Madrasah daripada aliran reformisme tumbuh dengan begitu pesat sekali. Aliran ini telah mendapat momentumnya di Malaysia apabila aliran reformisme (asalnya daripada aliran kaum Muda) diterima secara meluas oleh IPT di Malaysia. Manakala fahaman tradisionalism (asalnya aliran kaum Tua) tetap kekal di Malaysia dan Indonesia yang bertumpu di pondok-pesantren tradisional (Rahimin Affandi Abdul Rahim, 2000, h. $21-43)$.

2. Agensi agama Islam di Malaysia tetap kuat berpegang kepada aliran tradisional kerana mereka telah membentuk status quo yang tersendiri (Rahimin Affandi Abdul Rahim, 2008).

Pada penghujung tahun 1930-an, isu pertentangan kaum muda-kaum tua telah mula beransur hilang disebabkan oleh beberapa faktor semasa yang timbul di kalangan masyarakat Melayu seperti dominasi golongan nasionalis Melayu memperjuangkan kemerdekaan Tanah Melayu (Mohd. Sarim Mustajab, h. 150). Keadaan ini telah mendorong sesetengah sarjana mengatakan bahawa kaum muda telah gagal dalam usaha mereka menjalankan usaha tajdid di Tanah Melayu (Ibrahim Abu Bakar, h. 171-172). Kenyataan ini sebenarnya tidak berasas kerana usaha tajdid kaum muda dalam kontek sejarah Malaysia telah meninggalkan banyak kesan jangka panjang dan juga kesan jangka pendek. 
Dilihat dari kesan jangka pendek, kaum muda telah menglahirkan golongan intelektual Melayu yang dapat menganalisa perkembangan baru yang timbul di dalam masyarakat Melayu akibat dari dasar pemodenan kuasa British. Kesedaran ini kemudiannya telah mencetuskan kesederan politik (nasionalisme) orang Melayu yang melahirkan beberapa pertubuhan politik berteraskan Islam dan Melayu seperti HAMIM, PAS, dan KMMM. Pertubuhan-pertubuhan ini kemudiannya menyebarkan beberapa intipati utama gerakan tajdid kaum muda seperti penekanan kepada kepentingan akal dan logik, tauhid, kepentingan pendidikan moden, pembangunan ekonomi bangsa Melayu, demokrasi dan perpaduan umat Islam sejagat (Mohd. Sarim Mustajab, h. 151-152).

\section{Jalinan dakwah dan intelektual di Zaman Kebangkitan Semula Islam (Tahun- tahun 1970an-1990an)}

Di akhir dekad 70an dan permulaan dekad 80an, sepertimana masyarakat Islam luar, keadaan di Malaysia juga telah dilanda dengan gelombang kebangkitan semula Islam. Arus ini adalah ditandai dengan munculnya kesedaran untuk menyerap dan menegakkan nilai-nilai dan etika Islam dalam seluruh kehidupan (Husin Mutalib, 1990, h. 127-147) yang diperjuangkan oleh sejumlah besar pertubuhan Islam seperti ABIM, PAS, Tabligh, Arqam, PERKIM, USIA dan sebagainya.

Hasrat dan keinginan kepada penghayatan Islam ini kemudiannya telah turut sama diterima oleh pihak kerajaan sendiri. Dua contoh utama boleh diberikan dalam soal ini. Pertama, asas dan kaedah gerakan reformasi yang digambarkan oleh Walid Saif sebagai "The reformist moderate model which advocates the use of peaceful means to produce desirable changes. The stress here is on evolution rather than revolution. One of the basic common ideas in this context is to build up general awareness and opinion and to create a wide public base through education, guidance, the establishment of effective Islamically oriented service and public institutions" (Walid Saif, 1995, h. 59-60) telah diterima pakai oleh pihak kerajaan, memandangkan ianya secara langsung tidak mencabar kewujudan dan keabsahan pihak kerajaan. Sebaliknya, mengikut kaca mata pihak kerajaan, dasar dan prinsip golongan reformasi ini sekiranya dilaksanakan akan menghasilkan suatu dasar yang cukup baik dan teratur, dan apa yang lebih penting lagi ia dapat memberi peluang kepada pihak kerajaan untuk mengelola dan mengawasi gerakan golongan reformasi ini (W. Roof, 1988, h. 221-222).

Contoh yang kedua ialah gagasan anti sekularisme yang diperjuangkan oleh badan dakwah dan juga sarjana tempatan telah diterima baik oleh pihak kerajaan yang kemudiannya mencetuskan dasar Islamization. Selain dari faktor untuk menolak populariti parti pembangkang (W. Roof , 1988, h. 151-156). Menurut Prof. Muhammad Kamal Hassan, dasar ini pada asasnya dibuat berdasarkan beberapa prinsip utama iaitu (Muhammad Kamal, 1996, h. 107-110); 
Pertama, proses meletakkan Islam sebagai al-din (way of life) seperti mana yang pernah dilakukan pada zaman sebelum kedatangan kuasa British. Ia juga disifatkan sebagai proses membebaskan diri daripada warisan peninggalan penjajah dan Kedua,proses mengubah fahaman sekularisme (desecularization) yang telah menyerap masuk ke dalam seluruh kegiatan kehidupan dan jentera pentadbiran di negara Malaysia yang merdeka, dan ketiga, proses memperbetulkan perancangan dan pelaksanaan kebanyakan dasar pembangunan negara yang sebelumnya telah dipengaruhi sepenuhnya dengan fahaman sekularisme.

Di zaman ini, seperti mana halnya dengan zaman sebelumnya, perkaitan dan jalinan dakwah serta intelektualism di antara dua kawasan Malaysia Indonesia masih lagi wujud, berasaskan semangat ukhuwwah seperti mana yang terjalin di zaman sebelumnya. Antara jalinan yang dimaksudkan ini merangkumi;

Pertama, penyatuan idea dan kerjasama membabitkan gerakan Islam di Malaysia dan Indonesia. Hal ini boleh dilihat dari pendekatan aspek latihan dakwah antara gerakan Islam di dua kawasan dan juga penggunaan pendapat sarjana-sarjana Islam Indonesia oleh gerakan Islam di Malaysia, di dalam menanggani kebanyakan isu-isu yang timbul di Malaysia. Untuk memperjelaskan lagi kenyataan ini kita boleh mengemukakan beberapa perkara penting, seperti ABIM mempunyai hubungan yang rapat dengan Himpunan Mahasiswa Islam (HMI) (Victor Tanja, 1982), yang dilaporkan telah turut serta menghadiri Seminar Pengkaderan anjuran HMI ini pada tahun 1970 yang diadakan di Pekalongan, Indonesia. Sejak itu, kebanyakan formula latihan kepimpinan dan dakwah yang diamalkan oleh HMI telah turut diterimapakai oleh ABIM. Begitu juga, ABIM telah menyanjung tinggi pendapat dan pandangan yang diberikan oleh tokohtokoh HMI seperti Dr. Deliar Noer, M. Imaduddin Abdul Rahim dan Azyumardi Azra.

Contoh lain, pendekatan perjuangan yang berbentuk reformism yang disertakan dengan perancangan blueprint yang lengkap mengantikan pendekatan secara retorik semata-mata yang diamalkan oleh Muhamadiyyah (Nasir Tamara, 2000, h. 367-372) telah ditiru oleh kebanyakan gerakan Islam di Malaysia, dengan menubuhkan beberapa program dan institusi bentuk ini seperti KOHILAL, KBI, Sekolah al-Amin, TASKA, TASKI dan sebagainya, sebagai usaha menanggani persoalan yang timbul di dalam masyarakat (Husin Mutalib, h. 136-138). Begitu juga, ABIM dengan kerjasama Dewan Bahasa dan Pustaka telah menganjurkan seminar tentang Hamka dan transformasi sosial di Alam Melayu, yang mengkhususkan sumbangan yang telah diberikan oleh Hamka selaku sasterawan, sejarahwan, pemikir sosial, ahli tafsir dan novelis, yang amat berpengaruh di Malaysia. Seminar ini sekali lagi telah menonjolkan sumbangan Hamka selaku intelektual ummah seperti mana tokoh-tokoh lain yang memang begitu terkenal di rantau Alam Melayu (Peter Riddel, 2001; Hashim Musa, 2001). 
Kedua, pandangan dan banyak dari karya intelektual sarjana Indonesia telah mendapat sambutan yang baik dari kalangan sarjana Malaysia. Apa yang jelasnya, berbanding dengan realiti Malaysia, suasana budaya ilmu di Indonesia adalah lebih pesat dan begitu prolifik sekali. Hal ini terbukti dengan wujudnya kesungguhan usaha penterjemahan karya ilmiah Islam dan penghasilan karya ilmiah yang lebih original oleh kalangan sarjana Indonesia. Rata-ratanya bukubuku ilmiah dari Indonesia ini, samada dalam bentuk terjemahan dan karya original telah membanjiri kebanyakan kedai buku terkenal di Malaysia, yang memungkinkan pengaliran pengaruh intelektual ala Indonesia ini memasuki alam ilmiah Malaysia.

\section{Jalinan Sarjana Kedua Kawasan dalam Wacana Islamisasi Ilmu}

Gagasan Islamisasi ilmu ini antara lainnya mempunyai beberapa intipati utama; Pertama, ilmu yang dipakai dalam kontek dunia semasa yang rata-ratanya dipegang oleh masyarakat dunia adalah hasil pemakaian world-view dan sistem epistemologi sekularisme barat memang bertentangan dengan prinsip Islam yang wajib ditentang oleh umat Islam.

Kedua, ilmu barat dalam semua disiplin penuh dengan keburukan yang mmberi kesan yang merosakkan sistem ekologi dan merosak jiwa manusia. Ia akan membawa lebih banyak masalah kepada umat manusia. World-view Sekularisme barat menolak agama sebagai neraca ilmu dan kebenaran di dalam kehidupan manusia, sebaliknya agama dikatakan sebagai punca penderitaan umat manusia (Idris Zakaria, 1999, h. 15-21). Sebagai gantinya, manusia moden yang inginkan kemajuan perlu bergantung sepenuhnya kepada akal manusia sematamata.

Dalam konteks penguasaan ilmu pengetahuan, pergantungan kepada akal manusia ini telah ditumpukan kepada dua aspek yang utama, (i) memahami hakikat, kebenaran dan matlamat hidup manusia dan (ii) mempergunakan akal tanpa bimbingan wahyu untuk tujuan pengurusan dan pembangunan hidup manusia. Dalam aspek yang (i), perbincangan tentang elemen epistemologi (isu sumber, status dan neraca penilaian sesuatu ilmu) ini telah melahirkan dua aliran, rationalisme; akal sebagai sumber utama ilmu dan aliran empericisme; pengalaman sebagai sumber ilmu dan kebenaran. Kedua-dua aliran ini pada dasarnya menolak semua elemen ketuhanan dalam kehidupan manusia. Begitu juga dalam aspek ke (ii), proses pengurusan dan pembangunan hidup manusia lebih bertumpu kepada matlamat memberikan kepuasan kebendaan dan nafsu manusia.

Asas world-view sekularisme ini kemudiannya melahirkan falsafah humanisme (Muhammad Kamal Hassan, 1996)- menumpukan semua urusan pembangunan kehidupan dunia ini tanpa pertimbangan Akhirat semata-mata untuk kepuasan diri dan nafsu manusia. Falsafah ini kemudiannya telah 
melahirkan sejumlah besar paradigma disiplin keilmuan bagi tujuan pengurusan dan pembangunan tamadun materialistik. Ianya terdiri;

Pertama, paradigma Logikal emperikal positivisme - bagi setiap kajian keilmuan dan dianggap sebagai satu-satunya cara untuk mendapatkan ilmu yang paling tepat dan betul, yang kononnya dibuat melalui kaedah yang cukup sistematik, teliti dan objektif (Mohd Natsir Mahmud, 1997, h. 10-12). Manakala pengkajian yang berpandukan sumber wahyu akan dianggap sebagai tidak saintifik dan tidak boleh dibuktikan secara emperikal (semua perkara yang boleh ditangani secara lahiriah dengan pancaindera) (Abdul Rahman Abdullah, 2010, h. 71-72). Pendekatan ini pada dasarnya berpunca dari sikap mereka yang menolak agama dan perkara-perkara ghaib yang tidak dapat dilihat dan ditangani dengan pancaindera (Louay Safi, 1998, h. 190-199).

Kedua, pemakaian paradigma Materialistik-Mekanisme perlu dipakai sepenuhnya dalam proses membangunkan aspek fizikal yang membabitkan alam sekitar di dalam sesuatu masyarakat. Paradigma ini menganggap alam sebagai sumber utama yang berupa material- mekanis semata-mata dan tidak mempunyai nilai spiritual (nyawa) yang perlu bergantung kepada kuasa ketuhanan. Pandangan ini telah melahirkan sifat sekularis dan individualistik yang lebih menjurus kepada mementingkan kebajikan manusia berbanding dengan kebajikan alam. Hasilnya, berasaskan kepada paradigma ini, dua penekanan telah diberikan; (i) Alam dan segala isinya dianggap sebagai sumber utama yang bakal menambahkan kekayaan manusia sekularis- yang perlu diperah hasilnya semaksimum mungkin dan (ii) Alam perlu diteroka dan dikaji mengikut kerangka pemahaman saintifik -materalism-sekularisme agar segala hukumnya yang bersifat praktikal boleh dikaji demi untuk kepentingan manusia moden.

Intipati ketiga gagasan Islamisasi ilmu menetapkan bahawa sebelum ilmu barat dapat diterima ianya perlu ditapis dan disaring menggunakan sistem epistemologi Islam yang agak ketat. Mengikut Syed Naquibb al-Attas proses tapisan ini perlu mengambilkira world-view, ontologi, epistemologi dan aksiologi yang terkandung dalam ilmu barat. Lebih lanjut lagi, mengikut Ismail Faruqi, proses tapisan ini memerlukan beberapa langkah utama; (Zaini Ujang, 1989, h. 3942)

1. Menguasai disiplin ilmu moden (barat).

2. Kajian mendalam terhadap sesuatu disiplin barat.

3. Menguasai warisan ilmu Islam.

4. Analisis warisan ilmu Islam.

5. Mengemukakan kaitan Islam kepada sesuatu disiplin moden.

6. Penilaian terhadap disiplin ilmu moden.

7. Penilaian terhadap warisan ilmu Islam.

8. Kajian terhadap masalah ummah.

9. Kajian terhadap masalah manusia sejagat. 
10. Analisis dan sintesis terhadap kedua-dua disiplin moden dan Islam.

11. Penulisan buku teks yang mengandungi disiplin ilmu.

12. Menyebar luaskan ilmu yang telah diislamkan.

Mengikut pengamatan semasa, kita dapat mengesan beberapa yang membabitkan gagasan Islamisasi ilmu ini di Malaysia dan Indonesia, kesemuanya secara jelas memperlihatkan bahawa gagasan ini bukan setakat menjadi bahan wacana semata-mata, bahkan turut dilaksanakan intipatinya dalam kehidupan;

Pertama, persetujuan terhadap keburukan proses sekularisasi yang dibawa oleh penjajahan kuasa barat. Kesemua sarjana Islam di kedua kawasan bersetuju bahawa proses penjajahan kuasa barat (British dan Belanda) telah menyebabkan berlakunya proses sekularisasi dalam semua aspek kehidupan masyarakat Islam, terpenting lagi fahaman ini telah meresap dalam pemikiran masyarakat Islam. Ianya terdiri daripada;

i. Pengosongan alam tabii dan akal insani daripada unsur ketuhanan manusia bebas melakukan sesuatu program pembangunan tanpa mempedulikan kuasa tuhan.

ii. Penafian terhadap kekuasaan politik yang berdasarkan sumber agama.

iii. Pengenalan sistem penilaian nisbi/relatif terhadap agama; manusia bebas tentukan masa depannya sendiri.

iv. Penurunan taraf ilmu agama, berbanding dengan ilmu bukan agama tumpuan lebih diberi kepada ilmu bukan agama yg kononnya boleh membawa kemajuan (Mohd Hazim Shah Abdul Murad, 2005, h. 91- 92).

v. Penakrifan konsep kebenaran (truth) yang keliru dan mengikut paradigma sekularisme.

Kedua, penubuhan NGO/LSM khusus yang memperjuangkan gagasan Islamisasi Ilmu. Dewasa ini, perjuangan menegakkan usaha pelestarian Islam dalam masyarakat dikatakan boleh dibuat melalui beberapa cara; terlibat dalam sistem pemerintahan, pendidikan dan NGO. Sarjana Islam di kedua kawasan rataratanya bersepakat bahawa peranan NGO Islam amat diperlukan bagi memperjuangkan sesuatu gagasan tertentu. Bahkan dalam ketiga aspek yang dinyatakan sebelumnya ianya bersifat complimentari antara satu sama lain bagi melestarikan Islam dalam masyarakat Islam.

Peranan NGO ini yang ditubuhkan atas tujuan tertentu dan dianggotai oleh sejumlah besar pakar ilmu (Intellectual Circle) memang mmpunyai sejarah yang panjang dalam memperkembangkan keilmuan Islam dalam pelbagai falsafah yang tersendiri. Di zaman klasik, walaupun ianya bukan bernama NGO tetapi intipati utama perjuangan intellectual circle ini memang menyamai konsep NGO di zaman moden ini. 
Di Malaysia, gagasan Islamisasi ilmu telah melahirkan beberapa NGO khusus. Selepas Malaysia mencapai kemerdekaan dan tersebarnya gelombang kebangkitan semula Islam di tahun-tahun 1970-2000an, telah muncul intellectual circle saintis Melayu-Islam yang bernaung di bawah ASASI. Kebanyakan mereka terdiri daripada kakitangan akademik Melayu yang mendapat didikan daripada universiti di Barat, tetapi kuat terpengaruh dengan idealism Islam (Mohamad Abu Bakar, 2001, h. 407-410).

Kita boleh mengenalpasti beberapa peranan ASASI ini dalam memperjuangkan konsep sains Islam. Antaranya; pertama, melakukan kritikan dibuat terhadap konsep sains Barat. Butiran kritikan ini merangkumi penegasan bahawa masyarakat Melayu seolah-olah tertipu apabila menganggap sains Barat berfahaman sekular yang berasaskan logico positivisme sebagai paling benar dan universal pengunaannya. Sedangkan konsep sains Barat ini sebenarnya dikritik hebat oleh golongan saintis Barat di Eropah sendiri (Mohd Hazim Shah Abdul Murad, 2005, h. 91-94).

Selain itu juga, konsep sains Barat yang diagung-agungkan sebenarnya sains yang paling muda usianya berbanding dengan ilmu sains yang berteraskan ciri tempatan dan ada hubungan dengan tuhan (Abdul Rahman Abdullah, 2010). Di Alam Melayu sendiri sebelum kedatangan penjajah Barat telahpun ada warisan sains Melayu yang agak cemerlang (seperti meriam Melayu yang dilaporkan lebih hebat daripada meriam Portugis, kapal Melayu lebih kukuh daripada kapal Eropah). Memang ada manuskrip Melayu yang mengandungi semua maklumat sains Melayu ini (Shaharir Mohamad Zin, 2003, h. 157-203).

Apa yang jelasnya, Intellectual circle Melayu semasa seperti GAPENA dan ASASI secara kuat memperjuangkan tentang kemampuan bahasa Melayu digunakan sebagai bahasa ilmu untuk pengembangan ilmu sains. Mereka secara terang-terangan mencabar dakwaan bahawa bahasa Melayu tidak mampu digunakan untuk membangunkan pengetahuan bertaraf tinggi seperti konsep sains Islam. ASASI memperjuangkan gagasan Pemeribumian sains Melayu-Islam. Mengikut Osman Bakar, status negara Malaysia yang maju hanya akan dapat dicapai apabila masyarakat Melayu membangunkan kaedah sainsnya sendiri, di mana sains Barat diterima dan ditapis secara selektif dengan sains Melayu-Islam. Dengan cara ini, masyarakat Melayu akan mempunyai kekuatan dari segi peralatan, bahkan juga pemikiran (Osman Bakar, 1989 h. 10). Sebelum kedatangan kuasa penjajah, masyarakat Melayu telahpun mempunyai pengetahuan dari segi sains dan teknologi. Antaranya dalam bidang astronomi, astrologi, kosmogeni, matematik, perubatan, fizik dan sains hayat.

Di Indonesia pula, pelbagai NGO Islam muncul seperti INSIST yang membawa usaha penentangan terhadap fahaman liberalism barat yang mempengaruhi ajaran Islam. Ia lebih berbentuk Counter Attack dengan usaha yang dijalankan oleh golongan Islam liberal. Mengikut pandangan INSIST, konsep 
kelimuan barat tidak harus diterima begitu sahaja, tetapi perlu dilihat kepada world-view yang mendasari keilmuan tersebut.

World-view adalah pandangan manusia tentang diri, alam dan kehidupan. Ianya ditentukan oleh agama, budaya, falsafah dan perkembangan S\&T, yang secara langsung mempengaruhi sikap dan tindakan seseorang. Mengikut Hamid Zarkashi, world-view Islam adalah : visi tentang realiti dan kebenaran, berupa kesatuan pemikiran yang arsitektonik, yang berperanan sebagai asas yang tidak nampak (non-observable) bagi semua perilaku manusia, termasuk aktiviti ilmiah dan teknologi. Antara elemen asas untuk world-view Islam terdiri dari konsep tuhan, wahyu dan penciptaannya, psikologi manusia, ilmu, agama, kebebasan, nilai dan kebajikan dan kebahagiaan. Elemen-elemen inilah yang kemudiannya yang menentukan bentuk perubahan (change), perkembangan (development) dan kemajuan (progress) dalam Islam (Hamid Fahmy Zarkasyi, 2004, h. 1-6). Atas dasar ini, ternyata keilmuan barat moden memang memiliki elemen fahaman sekularisme yang terkandung di dalamnya yang harus ditentang oleh umat Islam.

Apa yang diperjuangkan oleh INSIST ini ternyata bertepatan dengan realiti wujudnya penganut aliran liberalism yang berpegang dengan paradigma taasub melulu dengan semua elemen daripada barat yang dianggap sesuai dengan konteks zaman moden. Lebih penting lagi, kumpulan Islam liberal ini telah menimbulkan pelbagai isu liberalism yang merangkumi isu penindasan wanita, ketertutupan Islam dengan perkembangan moden dan sikap anti terhadap golongan bukan Islam (Abd Moqsith Ghazali, 2007, h. 412-431). Sebagai contohnya, Luthfi Assyaukanie, menegaskan bahawa sekularisme tidak bercanggah dengan Islam, malah ia memberi berkah kepada Islam dan agamaagama lain. Menurutnya lagi sebuah demokrasi yang baik hanya boleh dilaksanakan jika ia mampu menerapkan prinsip-prinsip sekularisasi yang benar. Amerika Syarikat, Australia dan negara-negara lain tidak menganggap sekularisme sebagai musuh agama, bahkan pelindung agama. Penerapan yang sebeginilah yang disarankan oleh Luthfi Assyaukanie untuk mendapat berkah sekularisme (Luthfi Assyaukanie, 2007, h. 241-244).

Ketiga, penerapan gagasan Islamisasi ilmu dalam sistem pendidikan tinggi Islam. Di Malaysia, gagasan Islamisasi ilmu telah dijadikan falsafah dan asas utama penubuhan UIAM, USIM dan kemudiannya diterap sama oleh beberapa IPT yang menawarkan disiplin pengajian Islam. Di Indonesia, beberapa UIN juga dilihat berusaha menerapkan falsafah Islamisasi ini dengan menggunapakai pelbagai teori pendidikan yang berbeza, walaupun falsafahnya tetap sama; mengakui kelemahan sistem pendidikan Islam dan keperluan melakukan Islamisasi ilmu. Ia dikesan membawa Teori Integrasi Ilmu Agama Dan Umum, Teori Peta Laba-Laba, Teori Jaringan Roda Dan Teori Menara Berkembar. Terpenting sekali, kita mendapati sarjana Malaysia kurang memberikan penekanan kepada aspek falsafah yang bersifat abstrak, tetapi lebih suka menerapkan aplikasi Islamisasi 
ilmu dalam kurikulum di IPTA. Hal ini berbeza dengan realiti di Indonesia, mereka lebih suka menumpukan perhatian kepada konsep dan falsafah Islamisasi ilmu, yang sayangnya soal aplikasi kurang diberikan penekanan.

\section{Penerusan Wacana Idealism Islam yang Anti Ekstremism}

Ia membabitkan penentangan terhadap pendekatan ekstremism dalam pemahaman agama Islam. Sarjana dari kedua kawasan bersepakat bahawa sebarang bentuk perjuangan yang menggunakan kaedah ekstremeism perlu ditentang kerana ianya bakal merosakkan citra Islam itu sendiri. Walaupun apapun nama dan tren perjuangan, mereka sepakat menolak elemen kekerasan yang melampau, yang boleh diperincikan sebagai; (Hashim Musa, 2004, h. 232)

Pertama, extremisme; melampaui batas dan keseimbangan apabila mentafsir dan melaksanakan sesuatu peraturan ataupun hukum secara ekstrem. Kedua, chauvisnisme; taksub apabila menganggap fikiran atau kumpulan sendiri adalah yang terbaik, manakala fikiran atau kumpulan lain tidak benar dan mesti ditolak. Ketiga, fanaticisme; tindakan membuta tuli (menghampiri psikosis) dalam mengikuti dan melaksanakan sesuatu cara, pendapat dan pendekatan sendiri tanpa mempedulikan bahkan menolak sekeras-kerasnya pendapat orang lain.

Memang terdapat serangkaian aktiviti dan pegangan melampau yang dijalankan oleh penganut Islam semasa, samada di Malaysia (Mohd Mizan Aslam, 2009, h. 145-157) ataupun Indonesia (Amir Santoso, 2007, h. 323-338; Haedar Nashir, 2007, h. 167-168), antaranya; Pertama, amalan melampau telah bertanggungjawab menyebabkan perpecahan dan pertumpahan darah sesama umat Islam yang cukup dashyat sekali. Contohnya boleh dilihat daripada peritiswa kematian Imam Shafi'I yang dipukul oleh penganut fanatic mazhab Maliki akibat perbezaan pendapat antara keduanya dalam satu isu furu'iyyah yang kecil sahaja. Begitu juga halnya, dengan pergaduhan antara pengikut mazhab Sunni dan Syiah di dalam isu-isu biasa yang sepatutnya boleh diselesaikan melalui perbincangan ilmiah.

Contohnya boleh dilihat kepada kes Pengeboman Bali. Dalam perbicaraan kes tersebut yang dibuat di mahmakah Indonesia yang turut dihadiri oleh keluarga mangsa, tertuduh utama yang bernama Amrozi telah tersenyum sinis dan mengatakan perkataan "go to hell with you infidel" kepada semua keluarga mangsa korban yang berada di dalam mahkamah tersebut. Pihak media Barat yang turut serta membuat liputan di dalam perbicaraan tersebut telah mengambil kesempatan menjadikannya sebagai isu utama yang menonjolkan bahawa Islam memang mengajar penganutnya bersikap zalim dan biadap terhadap golongan bukan Islam. Lebih khusus lag, peristiwa 11 September yang memusnahkan WTC dan Pentagon telah menyebabkan kuasa Barat yang dipimpin oleh Amerika Syarikat melakukan pencerobohan terhadap dua Negara umat Islam, Aghanistan dan Iraq. 
Kita dapat mengesan wujudnya pengaruh global salafi melampau yang didasarkan kepada mentality perang Salib dan Neo-kolonialisme Barat, khususnya terhadap kuasa Barat dan Zionisme, yang wajib digunakan kaedah kekerasan untuk menangganinya. Lebih buruk lagi, hal ini turut diperpanjangkan dengan faktor perbezaan mazhab dalam Islam, seperti kes perbezaan antara dua mazhab terbesar dalam Islam, Sunni dan Syiah - Kes Kumpulan al-Qaedah di bawah pimpinan Abu Mus'ab al-Zarkawi di Iraq. Bagi golongan ini, pembentukan sebuah pemerintahan Islam bukan sekadar suatu alternatif, tetapi suatu kewajiban Syar'i berdasarkan perintah dan kehendak Allah. Kerana itu setiap penganut Islam harus patuh dengan mematuhi kehendak Allah ini, khususnya pemerintahannya yang dijalankan oleh golongan ini - Kes pemerintahan Taliban di Aghanistan.

Memandangkan legitimasi pemerintah Islam didasarkan kepada syariah Allah, maka pemerintah yang tidak mematuhi syariah adalah tidak sah. Manamana pemerintah dan individu Islam yang tidak mematuhi syariah Allah akan dianggap bersalah dan kafir yang diperangi menggunakan konsep Jihad - Kes pembunuhan Anwar Sadat oleh pengikut kumpulan Takfir wa al-Hijrah.

Bagi golongan ini, program penentangan terhadap pemerintah Islam yang ingkar perlu diperluaskan untuk memerangi ulamak rasmi berserta dengan semua pasarananya (seperti masjid dan sekolah) yang dilihat bergabung dengan pihak pemerintah - Kes Jemaah Islamiyyah dan Front Pembela Islam di Indonesia. Jihad melawan kekafiran dan golongan yang bersimpati dengannya adalah dianggap sebagai tugas suci. Oleh sebab itu memerangi golongan ini diwajibkan ke atas semua Mukmin sejati, yang perlu juga diperluaskan kepada semua golongan awam dan kepentingan mereka. Seperti mana golongan Khawarij, golongan ini menuntut komitmen kesetiaan dan ketaatan yang total. Bagi mereka, seseorang itu dilihat dari segi status keagamaannya, hanya berada dalam dua keadaan sematamata; samada Islam ataupun kafir.

Mereka menegaskan bahawa golongan Kristian dan Yahudi dianggap sebagai kafir, dan bukannya sebagai Ahli Kitab kerana hubungan mereka dengan kuasa kolonialisme Barat dan Zionisme. Mereka dipandang sebagai rakan rapat dalam sebuah konspirasi Yahudi-Kristian melawan Islam dan dunia Islam. Akhirnya, generasi muda Islam digalakkan untuk terlibat di dalam memerangi golongan kafir sebagai anti tesi kepada golongan Islam, yang dikatakan bakal memperoleh status mati syahid seandainya sanggup mengorbankan dirinya dalam pengeboman berani mati.

Bersamaan dengan pendekatan ini, sarjana Islam dari kedua kawasan memperjuangkan agar umat Islam mengamalkan sikap selektif dengan keilmuan Barat (Lili Yulyadi Arnakim \& Ibnu Hamad, 2010, h. 3-10). Kita sering terperangkap dengan sikap melampau yang menolak kesemua perkara yang datang daripada Barat. Dalam soal keilmuan ini, sarjana dari kedua kawasan mengakui memang terdapat beberapa elemen positif yang dimiliki oleh 
masyarakat Barat, khususnya yang membabitkan dunia ilmu. Bagi elemen yang positif pula, kita dapat mengesan beberapa perkara yang boleh dijadikan input berguna untuk proses berfikir bagi umat Islam. Ianya terdiri daripada (Abdul Rahman Embong, 2003).;

1. Teori dan formula pembangunan barat adalah cukup dinamik dan sentiasa berubah.

2. Realiti masyarakat dan kepimpinan politik barat yang lebih telus dan demokratik. (civil society).

3. Barat sentiasa melakukan proses reviewing terhadap semua konsep dan paradigma silam yang diikuti dengan usaha penambahbaikian yang sepatutnya. Hal ini boleh dilihat daripada usaha sarjana dan masyarakat mengkritik kelemahan paradigma sekularisme silam - terbukti apabila mereka lebih mengamalkan sikap positif dengan keperluaan agama dalam hidup manusia. Ianya turut disertakan dengan usaha menitikberatkan dalam soal penjagaan sistem ekologi dunia.

4. Realiti kepimpinan politik barat yang lebih suka berpegang kepada hasil R\&D yang dijalankan oleh para ilmuan.

5. Tahap kemajuan ekonomi masyarakat barat yang lebih maju, khususnya membabitkan penguasaan dunia barat terhadap seluruh sistem di dunia, antara lainnya kerana dunia barat memiliki kecanggihan ilmu pengetahuan dan seterusnya mampu mendominasi semua elemen kehidupan dunia moden (Hashim Musa, 2004, h. 191-192). Dalam soal ini, Hashim Musa menegaskan, Amerika Syarikat sebagai tamadun teras barat kini mendahului negara-negara lain di dunia dalam pelbagai bidang kira-kira 20 tahun ke hadapan, seperti; mendahului bidang teknologi; memiliki sifat keusahawanan yang tinggi; setiap lapisan rakyatnya digalakkan membuat eksperimen dan inovasi yang bermula daripada kosong. Contohnya, apa yang dijalankan oleh Microsoft dan Dell Computers; membenarkan tenaga muda dalam organisasi bersuara dan memimpin jika berupaya; berjaya memupuk dan memanfaatkan akal fikiran tenaga muda yang aktif dan produktif untuk kemajuan organisasi dan komuniti.

6. Konsep modal insan barat menitikberatkan beberapa sifat yang amat diperlukan untuk kerjaya moden, merangkumi; (H. Syahrin Harahap, 1999, h. 11-25) tindakan menunda kesenangan jangka pendek untuk kesenangan jangka panjang; memanfaatkan waktu dan etos kerja yang cemerlang; yakin dengan keadilan dapat disebarkan kepada manusia; menekankan pengamalan budaya ilmu sebagai kaedah untuk melahirkan kreatifiviti akal yang tinggi, dan akhir sekali, menyanjung tinggi bakat dan kemampuan serta penghargaan diberikan berdasarkan prestasi dan bukannya berasaskan kepada paradigma feudalism. 


\section{Kesimpulan}

Sebagai rumusan akhir, kita boleh menegaskan bahawa terdapat beberapa intipati terpenting berkaitan dengan pendekatan dakwah serantau, jika dirujuk kepada perkembangan sejarah yang pernah berlaku di rantau Alam Melayu. Pertamanya, walaupun kita sering berbangga dengan perkembangan hidup yang lebih baik di zaman moden ini dan sering memandang rendah terhadap zaman silam, tetapi dilihat dari segi kedinamikan perkembangan Islam di zaman silam, ternyata ianya lebih baik berbanding dengan zaman moden ini. Keduanya, walaupun konsep dan tema dakwah serantau telah mula diperkenalkan pada zaman moden ini, pada hakikat sebenarnya dipandang dari sudut teori dan praktikalnya, ianya telah diamalkan secara menyeluruh sejak dahulu lagi oleh kalangan penganut Islam di Alam Melayu. Ketiganya, peranan yang cukup proaktif kearah melahirkan intelektual ummah yang terdiri dari ulamak terbilang yang sanggup berkorban demi menegakkan kalimah Allah di rantau Alam Melayu telah berjaya dimainkan oleh institusi pendidikan Islam silam. Akhir sekali, kita boleh melihat aura kehebatan jalinan dakwah dan intelektual silam masih lagi diteruskan sehingga pada masa sekarang membabitkan kedua-dua penganut dari kawasan Alam Melayu.

\section{Rujukan}

Abdullah Alwi haji Hassan. (2001). Adat Melayu mengikut perspektif perundangan orang Islam di Malaysia, dalam Adat Melayu Serumpun. Kuala Lumpur: DBP.

Abdullah Ishak. (1982). Pendidikan Islam dan pengaruhnya. Kuala Lumpur: DBP.

Abdullah Mohd. Said. (2003). Prosedur dan pelaksanaan penilaian dampak social, dalam Penilaian dampak social (Ed. Mohd Razali Agus). Kuala Lumpur : Utusan publication.

Abd. Jalil Borhan. (1996). Sumbangan ulama dalam perkembangan Islam di Alam Melayu. Jurnal Syariah, 4(2).

Abdul Halim el-Muhammady. (1992). Dakwah dan kesannya dalam kehidupan masyarakat Melayu tradisional, dalam Dinamika dakwah, suatu perspektif dari zaman awal Islam hingga kini. Kuala Lumpur: IPI.

Abdul kadir Muhammad. (1996). Sejarah penulisan hukum Islam di Malaysia. Kuala Lumpur: DBP.

Abdul Rahman Abdullah. (1982). Pemikiran umat Islam di Nusantara. Kuala Lumpur: DBP.

Abdul Rahman Abdullah. (1994). Gerakan anti penjajahan di Malaysia 1511-1950: Pengaruh agama dan tarikat. Kuala Lumpur: Penerbit Kintan. 
Abdul Rahman Abdullah. (1999). Falsafah alam semesta di Nusantara. Kuala Lumpur: Utusan Publication.

Abdul Rahman Abdullah. (2010). Wacana falsafah sains: Sejarah dan pemikiran. Pulau Pinang: IESDEV USM.

Abdul Rahman Aziz. Falsafah pembangunan. Sintok: Penerbit UUM.

Abdul Rahman Aziz. (2004). Pemugaran semangat patriotisme untuk pembangunan. Sintok: Penerbit UUM.

Abdul Rahman Embong. (2003). Pembangunan dan kesejahteraan: Agenda kemanusiaan abad Ke-21, syarahan perdana jawatan professor, Pada 26 September 2003. Bangi: Penerbit UKM, 2003.

Abdul Rahman Haji Ismail. (1995). Nasionalisme Melayu dan Nasionalisme Melayu setanah Melayu: Satu perbincangan tentang soal permulaannya, dalam Isu-isu pensejarahan (Esei Penghargaan Kepada Dr. S. Suntharalingam). Pulau Pinang.

Abd Moqsith Ghazali. (2007). Mengubah wajah fiqh Islam, dalam Abd Hakim dan Yudi Latif (Eds.), Bayang-bayang fanatisme: Esai-esai untuk mengenang Nurcholish Madjid. Jakarta: PSIK Universitas Paramadina.

Ahmad Kamal Abdullah. (1988). Unsur-unsur Islam dalam puisi Melayu moden. Kuala Lumpur: DBP.

Akh. Minhaji. (2003). Masa depan pembidangan ilmu di perguruan tinggi agama Islam. Jogjakarta: Percetakan ar-Ruzz Jogjakarta.

Amir Santoso. (2007). Radikalisme dan terorisme di Indonesia, dalam Mohd Izani Mohd Zain (Ed.), Demokrasi dan dunia Islam: Perspektif teori dan praktik. Kuala Lumpur: Penerbit UM.

Amran Kasimin. (1987). Perbendaharaan kata Arab dalam bahasa Melayu. Bangi.

Azyumardi Azra. (1999). Renaisans Islam Asia Tenggara: Sejarah wacana dan kekuasaan. Bandung: PT Remaja Rosdakarya.

Bagoes Wiryomartono. (2012). Historical notes, concepts, and evolution of urbanism in the Malay world, JATI, 17, December 2012.

Chamhuri Siwar. (2002). Paradigma pembangunan: Meneliti hubungan pertumbuhan ekonomi, penglobalan, kegawatan ekonomi dan pembasmian, dalam Misran Rokimin (Ed.), Falsafah dan peradaban pembangunan. Bangi: Penerbit UKM.

Charles Tisdall. (1916). Ideas of Mohammedan Malaya, dalam The missionary review of the world, v. xxxiv, 1916.

Che Su Mustaffa. (1996). Penerimaan idea-idea pembangunan di kalangan masyarakat Melayu: Satu analisis teori difusi", dalam Ahmad Fawzi Mohd. Basri (Ed.), Nilai orang Melayu. Sintok: Sekolah Pembangunan Sosial, UUM.

D.G. E. Hall. (1968). A history of South East Asia. London: St. Martins Press.

Faisal Ismail. (1997). Studi Islam Di Barat, Fenomena Menarik, dalam Yudian W. Asmin (Ed.), Pengalaman belajar Islam di Kanada. Yogyakarta: Titian Ilahi press. 
----. (2005). Islam Hadhari dalam pembinaan tamadun masa kini. Pemikir, bil. 39 \& 40, Januari-April-Jun 2005.

G.P. Means. (1969). The role of Islam in the political development in Malaysia. Comparative Politic, 1(2).

Haedar Nashir. (2007). Gerakan Islam syariat: Reproduksi Salafafiyah ideologis di Indonesia. Jakarta: PSAP.

Hamedi Mohd Adnan. (2006). Penerbitan Malaysia-Indonesia: mengukuhkan jaringan penerbitan serantau. Kuala Lumpur: Penerbit UM.

Hamid Fahmy Zarkasyi. (2004). Tantangan sekularisasi dan liberalisasi di dunia Islam. Surabaya: Penerbit Khairul Bayan.

Hashim Musa. (2004). Pemerkasaan tamadun Melayu Malaysia menghadapi globalisasi Barat. Kuala Lumpur: Penerbit UM.

----. (2001). Merekonstruksi tamadun Melayu Islam; Ke arah pembinaan sebuah tamadun dunia alaf ketiga. Kuala Lumpur.

Hassan Ahmad. (2004). Bahasa dan pemikiran Melayu: Tradisi dan kesinambungan, dalam Worawit Baru @ Haji Ahmad Idris (Ed.), Pemikiran Melayu: Tradisi dan kesinambungan. Kuala Lumpur: DBP.

Husin Mutalib. (1990). Islam and ethinicity in Malay politics. Singapore, 1990.

H. Syahrin Harahap. (1999). Islam; Konsep dan implementasi pemberdayaan. Yogyakarta: PT Tiara Wacaana Yogya.

Ibrahim Abu Bakar. (1994). Islamic modernism in Malaya. Kuala Lumpur.

Idris Zakaria. (1999). Intelek Eropah dan penentangan terhadap agama. AlMaw'izah, Bil. 7.

Ithnin Abdul Jalil. (2001). Pemikiran saintifik orang Melayu melalui peribahasa, dalam Yaacob Haron (Ed.), Kosmologi Melayu. Kuala Lumpur: APMUM, 2001.

Isabella Bird (1967). The golden Chersonese and the way thither. Kuala Lumpur.

Ismail Mat (1997). Pengajian syariah: Hubungannya dengan adat Arab dan keadaan di Malaysia, dalam Dinamisme pengajian syariah. Kuala Lumpur.

John Esposito (1996). Islam and democracy. Oxford.

Lili Yulyadi Arnakim \& Ibnu Hamad. (2010). Islamophobia and its discontents: The reduction of Muslims' self confidence in the information age, JATI, 15, December 2010.

Louay Safi. (1998). Asas-asas ilmu pengetahuan: Satu kajian perbandingan kaedahkaedah penyelidikan Islam dan Barat, Terj. Nur Hadi Ihsan. Kuala Lumpur.

Mahayudin Haji Yahya. (1999). Masyarakat Madani dalam kerangka teori masyarakat Umran, dalam Jurnal Pendidikan Islam, 8(4).

Mohd. Anis Md. Nor. (1990). The Zapin Melayu dance of Johor: From village to a national performance tradition, Tesis PhD, University of Michigan.

Mohd Hazim Shah Abdul Murad. (2005). Epistemology colonial: Satu analisis ciri dan kesannya, dalam Mohamad Daud Mohamad (ed.), Pascakolonialisme dalam pemikiran Melayu. Kuala Lumpur: DBP. 
Mohd Mizan Aslam. (2009). The thirteen radical groups: Preliminary research in understanding the evolution of militancy in Malaysia, JATI, 14, December.

Mohd Natsir Mahmud. (1997). Orientalisme: Al-Quran di mata barat (Sebuah studi evaluatif). Semarang.

Mohd. Sarim Mustajab. (1982). Gerakan Islah Islamiyyah di Tanah Melayu: 19061948, dalam Malaysia: Sejarah dan proses pembangunan. Kuala Lumpur.

Mohd. Taib Osman. (1989). Malay Folk Beliefs: An Integration of Disparate Elements. Kuala Lumpur: DBP.

Mohd. Yusof Iskandar. (1982). Masyarakat Melaka 1400-1511 T.M. dengan tinjauan khusus mengenai orang-orang asing, dalam Malaysia: Sejarah dan proses pembangunan. Kuala Lumpur.

Mohamad Abu Bakar. (2001). Pengaruh luar dan pengislaman dalam negeri: United Kingdom dan Eire dalam kebangkitan semula Islam di Malaysia, dalam Mohammad Redzuan Othman (ed.), Jendela Masa: Kumpulan esei sempena persaraan Dato' Khoo Kay Kim. Kuala Lumpur: Penerbit Universiti Malaya.

Mohamad Raduan Mohd Ariff \& Shaharil Talib. (1995). Penulisan dan realiti sejarah Asia Tenggara: Satu persoalan. JATI, l, September 1995.

----.. (1997). The water cities of the Asiatic Archipelago, JATI, 3, Ogos 1997.

Mohammad Redzuan Othman. (1994). The Middle Eastern Influence on the development of religious and political thought in Malay society, 1880-1940. Tesis PhD untuk University of Edinburgh.

----. (2001). Pengaruh Timur Tengah dalam perkembangan awal kesedaran politik Melayu, dalam Jendela Masa. Kuala Lumpur.

----. (1998). The Role of Makka-Educated Malays in the Development of Early Islamic Scholarship and Education in Malaya. Journal of Islamic Studies, 9(2), (1998).

Meor Ahmad Noor Mior Hamzah. (2001). Konsep sempadan negeri dalam masyarakat, JATI, 6, Disember 2001.

M.Rajantheran. (2001). Amalan Kultus Devaraja di Asia Tenggara, JATI, 6, Disember 2001.

M.B. Hooker. (1976). The Terengganu in Malayan legal history. JMBRAS, v. XLIX, part 2.

Muhammad Kamal Hassan. (1996). Toward actualizing Islamic ethical and educational principles in Malaysia. Kuala Lumpur: ABIM.

Nabir Abdullah. (1987). Turki dan alam Melayu: Tinjauan terhadap sejarah hubungan keduanya. Jebat, 15, (1987).

Nasir Tamara. (2000). The Ummah: Rising to the challenges with special reference to Indonesia, dalam Mohd. Taib Osman (Ed.), Islamic civilization in the Malay World. Kuala Lumpur, 2000. 
Osman Bakar. (1989). Perkembangan penting dalam pemikiran sains masa kini: Satu tinjauan umum, dalam Osman Bakar (ed.), Islam dan pemikiran sains masa kini. Kuala Lumpur: ASASI.

Omar Awang. (1981). The major Arabic sources which determined the structure of Islamic thought in the Malay Archipelago before the nineteenth century a.d. in the field of law, theology and Sufism, dalam ISLAMIKA,v. 1. (1981).

Omar Awang. (1980). The Trengganu inscription as the earliest known evidence of the finalisation of the Jawi alphabet. Federation Museums Journal, 25.

Peter Riddell. (2001). Islam and the Malay-Indonesian World. London.

Rahimin Affandi Abd. Rahim. (2000). Fiqh Malaysia: Suatu tinjauan sejarah, dalam Figh Malaysia, Ke arah pembinaan figh tempatan yang terkini. Sungai Buloh: APIUM.

----. (2011). Tradisi intelektual Melayu-Islam: Daripada metafora kepada saintifikisme. Jurnal Melayu: The Muslim World Journal (Edisi Khas)..

----. (2013). Islam dan kearifan tempatan di alam Melayu: Analisis kritikal. JATI, 18, December 2013.

----. (2009). Pembangunan sains dan teknologi di IPTA Islam di Malaysia: Satu analisis sejarah", Jurnal ESTEEM, 5(2).

-----. (2005). Citra Islam dalam pembentukan manusia Melayu moden di Malaysia: Suatu analisa. Jurnal Pengajian Melayu, 15.

-----. (2010). Pembaharuan pemikiran hukum Islam di Indonesia, JATI, 15, December 2010.

------. (2003). Analisis sejarah dakwah dan jalinan intelektuaal rantau MalaysiaIndonesia, dalam Zulkiple Abd. Ghani (Ed.), Jaringan dakwah MalaysiaIndonesia. Terbitan Jabatan Pengajian Dakwah dan Kepimpinan, UKM dan Universitas Muhammadiyah Sumatera Utara (UMSU).

-----. (2005). Isu pendekatan di dalam pengajian syariah di Malaysia: Satu telaah awal. Jurnal Syariah, 13(1).

------. (2000). Kebudayaan Melayu dan Islam di Nusantara: Satu analisa pengkaedahan, dalam Seminar Hukum Islam Semasa 111 Peringkat Kebangsaan 2000. Anjuran Jabatan Fiqh dan Usul, Akademi Pengajian Islam Universiti Malaya, pada 7-8hb. November 2000.

-----. (2008). Pendekatan Malaysia dan Indonesia dalam menangani perkembangan aliran pemikiran Islam: Satu analisis perbandingan, Jurnal Jati, 13.

Rumaya Juhari. (2004). Pengantar pembangunan manusia: Perspektif ekologi. Serdang: Penerbit UPM.

R.O. Winstedt. (1932). A history of Malaya. JMBRAS, V. X.

Saleh Faghizadeh. (2004). Sosiologi Sosiologi, Terjemahan oleh Mohd Fauzi Yaacob. Kuala Lumpur: ITNMB.

Shafie Abu Bakar. (1994). Keilmuan Islam dan tradisi pengajian pondok, dalam Budi Kencana. Kuala Lumpur: DBP. 
-----. (1987). Ruba'i: Pengaruhnya di dalam kesusasteraan Melayu, dalam Cendekia kesusasteraan Melayu Tradisional. Kuala Lumpur: DBP.

Shaharir Mohamad Zin. (2003). Sains dan teknologi Melayu sebelum penjajahan Eropah, dalam Melayu: Jurnal Antarabangsa Dunia Melayu, 1(2).

Shaharil Talib. (1997). The Asiatic Archipelago: History beyond boundaries, JATI, 3, Ogos 1997.

Siti Hawa Haji Salleh. (1987). Kesusasteraan hikayat sebagai suatu genre : Suatu perbincangan berdasarkan hikayat Ismayatim, dalam Cendekia Kesusasteraan Melayu Tradisioanal. Kuala Lumpur: DBP.

S. Hossein Nasr. (1990). Traditional Islam in the modern world. London: Kegan Paul International.

Toto Suharto. (2003). Epistemologi sejarah kritis Ibn Khaldun. Yogyakarta: Fajar Pustaka Baru.

Walid Saif. (1995). Human rights and Islamic revivalism, dalam Religion, Law and Soceity: A Christian-Muslim Discussion. Geneva.

William Roff. (1980). The origins of Malay Nationalism. Kuala Lumpur: Oxford University Press.

-----. (1988). Patterns of Islamization in Malaysia 1890s-1990s: Exemplars, institutions and vectors. Journal of Islamic Studies, 9(2).

Yusri Ihza Mahendra. (1994). Studi Islam di Timur dan Barat: Pengaruhnya terhadap pemikiran Islam di Indonesia. Ulumul Quran, 3(3).

Victor Tanja. (1982). Himpunan mahasiswa Islam: Sejarah dan kedudukannya di tengah gerakan-gerakan Muslim pembaharuan di Indonesia.Jakarta.

Zaini Ujang. (1989). Tinjauan terhadap pendidikan bersepadu: suatu sorotan dalam pengajian kejuruteraan alam sekitar. Jurnal Pendidikan Islam, 2(1). 